\title{
MANAJEMEN RISIKO UNIT USAHA SYARIAH BANK PEMBANGUNAN DAERAH JAMBI PADA PEMBIAYAAN MURABAHAH MODAL KERJA
}

\author{
Ahmad Syahrizal \\ Perbankan Syariah, UIN Sulthan Thaha Saifuddin Jambi \\ ahmadsyahrizal@uinjambi.ac.id
}

\begin{abstract}
Abstrak
Penelitian ini dilakukan untuk mengetahui bagaimana penerapan manajemen risiko pada pembiayaan murabahah modal kerja Unit Usaha Syariah Bank Pembangunan Daerah (BPD) Jambi. Pembiayaan murabahah modal kerja memiliki risiko yang cukup besar dibandingkan pembiayaaan lainnya sehingga Unit Usaha Syariah BPD Jambi dituntut untuk menyusun, menetapkan dan menerapkan manajemen risiko yang baik. Metode yang digunakan dalam proses penelitian adalah studi empiris dengan metode kualitatif deskriptif berdasarkan data dan informasi yang didapatkan dilapangan. Berdasarkan hasil penelitian didapati bahwa dalam pembiayaan murabahah modal kerja Unit Usaha Syariah BPD Jambi telah menerapkan manajemen risiko yang cukup baik dengan adanya proses identifikasi risiko-risiko yang yang bisa saja terjadi dalam pembiayaan, adanya pengukuran risiko-risiko yang kemungkinan terjadi dengan mengamati dan membaca data serta riwayat pembiayaan calon nasabah, adanya pengelolaan dan pengendalian risiko dengan sistem tagihan, penerbitan surat peringatan serta mediasi penyelesaian permasalahan pembiayaan nasabah. Manajemen risiko yang diterapkan tergolong efektif dengan adanya peningkatan capaian pada pembiayaan murabah modal kerja tersebut.
\end{abstract}

\section{Kata Kunci : Manajemen Risiko, Pembiayaan Murabahah Modal Kerja}

\begin{abstract}
This research was conducted to find out how the application of risk management to the working capital murabahah financing of the Jambi Regional Development Bank (BPD) Sharia Business Unit. Murabahah financing for working capital has a considerable risk compared to other financing so that BPD Jamb Sharia Business Units are required to develop, determine and implement good risk management. The method used in the research process is an empirical study with descriptive qualitative methods based on data and information obtained in the field. Based on the results of the study, it was found that in working capital murabahah financing the Sharia Business Unit of BPD Jambi had implemented a fairly good risk management with the identification process of risks that could occur in financing, the measurement of risks that might occur by observing and reading the data. as well as the financing history of prospective customers, the existence of risk management and control with a billing system, issuance of warning letters and mediation of settlement of customer financing problems. The risk. management applied is considered effective with an increase in the achievement of the working capital murabahah financing.
\end{abstract}

Keywords : Risk Management, Working Capital Murabahah Financing 


\section{Pendahuluan}

Perbankan syariah merupakan salah satu sektor industri yang cukup menjanjikan di Indonesia. Sebagai salah satu negara yang mayoritas penduduknya beragama Islam banyak pihak berkeyakinan bahwa perbankan syariah akan mudah diterima masyarakat dan cepat berkembang. Terbitnya berbagai regulasi tentang perbankan yang diawali dengan Undang-undang Nomor 7 tahun 1998 menandakan cukup tingginya dukungan pemerintah dalam penerapan sistem perbankan syariah di Indonesia. (Karim, 2007). Perkembangan perbankan syariah dinilai cukup baik dengan meningkatnya market share yang sudah mencapai 6,18 persen dengan nilai aset yang dimiliki senilai Rp545,39 triliun pada tahun 2020. (Snapshot Perbankan Syariah Juni 2020)

Melekatnya label syariah pada perbankan membuat risiko yang dihadapi dalam menjalankan usahanya juga akan menjadi lebih banyak jika dibandingkan dengan bank konvensional. Risiko merupakan potensi kerugian yang bisa saja terjadi disebabkan suatu peristiwa tertentu. Risiko akan selalu ada pada suatu benda ataupun kegiatan baik yang berwujud maupun abstrak karena risiko bersifat melekat maka dari itu risiko tidak bisa dihilangkan bahkan bisa saja menghindari satu risiko berarti mengadapi risiko yang lain.

Berdasarkan pada Peraturan Otoritas Jasa Keuangan (POJK) No. 65.03/2016 tentang Penerapan Manajemen Risiko Bagi Bank Umum Syariah dan Unit Usaha dalam pasal satu bahwasanya ada 10 bentuk risiko yang harus dihadapi dan dikelola oleh pengelola perbankan syariah yaitu Risiko Kredit, Risiko Likuiditas, Risiko Pasar, Risiko Operasional, Risiko Hukum, Risiko Strategik, Risiko Imbal Hasil, Risiko Investasi, Risiko Reputasi dan Risiko Kepatuhan. Lebih banyaknya risiko yang dimiliki seakan menunjukkan bahwa pengelolaan perbankan syariah lebih rumit jika dibandingkan bank konvensional yang hanya memiliki delapan risiko namun sebenarnya hal tersebut justru semakin mempermudah karena semakin jelas dan terarah dalam identifikasi risiko. (POJK No.6. 2016)

Banyaknya risiko yang bisa saja terjadi dan harus dihadapi mengharuskan adanya pengelolaan dan pengendalian yang baik dari perbankan syariah agar bisa mempertahankan dan memperluas usahanya terutama di tengah perkembangan era digital saat ini. Pengelolaan ini disebut sebagai manajemen (Syahrizal \& Anita, 2021). Risiko yang terjadi pada setiap perbankan tentunya akan berbeda-beda. Perbankan yang baik tentu akan mampu mengelola dan mengendalikan risiko yang terjadi sehingga diharapkan tingkat risiko bisa diminimalisir bahkan dihilangkan. Pengelolaan dan pengendalian ini tersusun secara sistematis dalam sebuah manajamen yang kemudian dikenal dengan manajemen risiko.

Manajemen risiko harus benar-benar dikelola dan dikuasai dengan sangat baik oleh perbankan syariah terutama pada produk pembiayaan karena pembiayaan merupakan sarana utama bagi perbankan syariah dalam mendapatkan profit bagi hasil. Pembiayaan merupakan suatu proses yang berawal dari analisis kelayakan pemberian fasilitas pembiayaan yang berujung pada realisasi pembiayaan tersebut. Tetapi realisasi pembiayaan bukanlah ujung terakhir dalam proses pembiayaan karena setelah bank merealisasikan pembiayaan kepada nasabah diperlukan pemantauan, pengawasan dan monitoring atas pembiayaan tersebut sebab dalam rentang waktu pembiayaan tidak menutup kemungkinan terjadinya pembiayaan bermasalah.(Prasastinah Usanti, 2019)

Secara umum pembiayaan pada Bank Syariah terbagi menjadi tiga kategori. Pertama. Pembiayaan modal kerja dengan jangka pendek dan sesaat yang sering diberikan 
kepada organisasi ataupun lembaga untuk memenuhi kebutuhan modal dari suatu bisnis. Kedua, pembiayaan dengan spekulasi syariah yakni pembiyaan yang sering diberikan dalam menangani problematika perdagangan maupun produk. Ketiga, pembiayaan pembelanjaan klien terhadap suatu aset yang berkaitan dengan pemanfaatan aset tersebut. (Eka Yudiana, 2014)

Pembiayaan dalam bank syariah tidak terlepas dari dua skema utama yaitu pembiayaan dengan skema jual beli dan pembiayaan dengan skema kerjasama. Dalam pembiayaan jual beli terdapat tiga akad utama yaitu murabahah, salam dan isthisna sedangkan dalam pembiayaan kerjasama terdiri dari akad mudharabah dan musyarakah. Berdasarkan pada laporan keuangan perbankan syariah rata-rata pendapatan paling besar disumbangkan oleh pembiayaan dengan skema jual beli menggunakan akad murabahah.

Akad murabahah meruapakan akad jual beli atas atau terhadap suatu barang dengan disebutkannya harga perolehan atas barang tersebut dan dibayar oleh pembeli dengan harga lebih yang diakui sebagai laba oleh penjual baik secara tertulis, lisan, isyarat, perbuatan maupun elektronik yang diakui dan sesuai dengan prinsip syariah serta undangundang yang berlaku (Fatwa DSN No. 111 Tahun 2017). Pembiayaan dengan skema jual beli menggunakan akad murabahah telah banyak dipraktikkan oleh lembaga keuangan dan perbankan syariah tak terkecuali oleh Unit Usaha Syariah Bank Pembangunan Daerah (BPD) Jambi.

Unit Usaha Syariah BPD Jambi merupakan unit usaha dari bank milik pemerintah Provinsi Jambi. Bank Jambi mulai berdiri pada tanggal 12 Februari 1959 melalui akta notaris Adiputra Perlindungan no.6 dan disempurnakan dengan akta notaris Habro Poerwanto nomor 70 pada tanggal 12 bulan Oktober ditahun yang sama dan disahkan oleh Menteri Kehakiman Republik Indonesia Nomor J.A/5/115/8 6 November 1955 hingga kemudian setelah kurang lebih 52 tahun berdiri tepatnya pada tanggal 23 Juni 2011 Bank Jambi mendapat rekomendasi dari MUI Provinsi Jambi untuk mendirikan Unit Usaha Syariah yang terealisasi pelaksanaan dan operasionalnya pada awal Januari 2012. (Bank Jambi, t.t)

Unit Usaha Syariah BPD Jambi dalam pembiayaan jual beli murabahah memiliki tiga produk unggulan yaitu Pembiayaan Murabahah Modal Kerja, Pembiayaan Murabahah Investasi dan Pembiayaan Murabahah Konsumtif. Pembiayaan Murabahah Investasi adalah bentuk jual beli antara pihak bank dan nasabah dengan tujuan investas sedangkan Pembiayaan Murabahab Modal Kerja adalam bentuk jual beli antara bank dan nasabah yang bertujuan untuk memberikan modal kerja bagi nasabah dan adapun Pembiayaan Murabahah Konsumtif adalah bentuk jual beli antara bank dan nasabah yang bertujuan untuk memenuhi kebutuhan konsumsi nabasah (Ulfa, 2019). Dalam pelaksanaannya, Unit Usaha Syariah BPD Jambi memiliki banyak risiko yang tidak bisa dihindari salah satunya risiko pembiayaan yang disebabkan hilangnya komitmen konsumen untuk memenuhi kewajibannya terhadap bank sesuai kesepkatan dan biasa disebut gagal bayar. (Sofyan, 2017)

Gagal bayar nasabah (default) secara umum dikelompokkan menjadi dua jenis yaitu nasabah yang mempunyai kemampuan untuk membayar namun sengaja tidak melakukan pembayaran dan nasabah yang tidak mampu membayar dikarenakan bangkrut maupun alasan lain yang dapat diterima yang berakibat tertunda dan gagalnya pembayaran. (Bambang, 2013) Pada Unit Usaha Syariah BPD Jambi, risiko pembiayaan terjadi ketika bank telah memberikan modal/barang kepada nasabah namun nasabah tersebut tidak 
dapat memenuhi kewajibannya dalam membayar yang berakibat pada menurunnya pendapatan bank dan naiknnya kredit macet.

Tabel 1. Data Nasabah Pembiayaan Murabahah Unit Usaha Syariah BPD Jambi per 30 April 2021

\begin{tabular}{|l|l|l|l|}
\hline \multicolumn{1}{|c|}{ Periode } & $\begin{array}{c}\text { Murabahah Modal } \\
\text { Kerja }\end{array}$ & \multicolumn{1}{|c|}{$\begin{array}{c}\text { Murabahah } \\
\text { Investasi }\end{array}$} & \multicolumn{1}{|c|}{$\begin{array}{c}\text { Murabahah } \\
\text { Konsumtif }\end{array}$} \\
\hline 30 April 2021 & 39 Nasabah & 37 Nasabah & 3.827 Nasabah \\
\hline Kredit Macet & 28 Nasabah & 25 nasabah & 13 Nasabah \\
\hline
\end{tabular}

Sumber : Admin Pembiayaan Unit Usaha Syariah BPD Jambi

Berdasarkan tabel tersebut terlihat bahwa risiko pembiayaan yang paling besar terjadi pada pembiayaan murabahah modal kerja dimana dari total 39 nasabah terdapat 28 nasabah yakni sekitar 71 persen masuk dalam kategori pembiayaan kurang lancar atau kredit macet. Tingginya risiko pembiayaan pada murabahah modal kerja ini perlu mendapatkan perhatian yang lebih dibandingkan pembiayaan lainnya karena bagaimanapun juga ketika pembiayaan diberikan berarti bank telah memberikan kepercayaan kepada nasabah untuk mendapatkan modal atau barang yang semestinya harus dikembalikan dan dibayar oleh nasabah bersama keuntungan yang telah disepakati dan jika tidak terbayar maka bisa dianggap sebagai kehilangan atau kerugian bagi bank.

Oleh karena itu sangat penting sekali penguasaan dan penerapan manajemen risiko oleh Unit Usaha Syariah BPD Jambi dalam pembiayaan murabahah modal kerja agar dapat mengidentifikasi, mengukur, mengelola dan mengendalikan risiko sebagai bentuk upaya mengatasi dan menghindari terjadinya kerugian. Manajemen risiko pembiayaan adalah suatu metode yang logis dan sistematik dalam mengidentifikasi, mengkuantifikasi, aksi, membuat solusi serta monitoring dan pelaporan risiko yang dilakukan pada setiap aktifitas pembiayaan. (Idroes, 2008) Jika manajemen risiko dapat diimplementasikan dengan baik pada lembaga perbankan maka akan dapat meningkatkan nilai perusahaan bagi shareholder nya serta semakin baik dan berkembangnya metode dan proses pengambilan keputusan berdasarkan data dan informasi yang dimiliki.

\section{Metode}

Penelitian ini menggunakan metode studi empiris yaitu penelitian yang didasarkan permasalahan terkait hal-hal yang berdasarkan data dan fakta informasi yang didapatkan dari penelitian langsung dilapangan dengan pendekatan kualitatif yang berfokus pada fenomena-fenomena dilapangan yang bersifat deskriptif. Metode dan pendekatan ini digunakan untuk mengetahui dan menggali infromasi atas objek penelitian yakni terkait manajemen risiko pembiayaaan murabahah modal kerja yang diterapkan oleh Unit Usaha Syariah BPD Jambi. Data atas objek ini bisa didapatkan melalui sumber informasi yang fundamental seperti teks, aktifitas kegiatan, dokumen, rekaman, foto dan lainnya yang sesuai dengan fokus penelitian (Moleong, 2018). Data dalam penelitian terdiri dari dua jenis yaitu primer dan sekunder. Data primer didapatkan dari sumber informasi utama yang esensial yaitu Kepala Cabang PT. Unit Usaha Syariah BPD Jambi Bapak Firsan Sadli, Bapak Ifik Kristen Wijaya sebagai Head Pembiayaan dan Ibu Devi Muthia Rizki sebagai Ketua Satuan Kerja Audit Intern serta beberapa nasabah pembiayaan. Sedangkan data sekunder merupakan suatu informasi yang didapatkan dari berbagai dokumen baik audio, visual dan teks(Sugiyono, 2011). 
Para responden yang menjadi narasumber pada penelitian ini merupakan sampel dari total populasi penelitian. Populasi adalah kumpulan individu atau satuan-satuan yang karakteristiknya akan diteliti sedangkan sampel adalah bagian yang diambil dari total individu maupun satuan populasi tersebut. Pengambilan sampel dilakukan dengan menggunakan metode Purposive Sampling yaitu penentuan sampel dengan pertimbanganpertimbangan tertentu (Yusuf, 2014). Salah satu contoh pertimbangan yang dimaksud adalah memilah sampel yang memiliki kuasa dan pegetahuan lebih dalam dan bersinggungan baik langsung maupun tidak langsung terkait manajemen risiko pembiayaan murabahah modal kerja di Unit Usaha Syariah BPD Jambi.

Data dalam penelitian ini dikumpulkan melalui tiga tekhnik utama yang sering digunakan dalam penelitian kualitatif yaitu observation, interview dan documentation. Observation merupakan teknik pengumpulan data dengan menggunakan indra penglihatan dan pendengaran. Dengan teknik ini peneliti mendatangi secara langsung Unit Usaha Syariah BPD Jambi untuk melakukan pengamatan terkait fokus penelitian yaitu penerapan manajemen risiko pembiayaan modal kerja murabahah baik terhadap pihak BPD sendiri maupun nasabah. Interview atau wawancara pengumpulan data dalam bentuk diskusi dan tanya jawab kepada narasumber secara open-endded-focus terhadap semua narasumber. Dalam hal pandemi Covid-19 saat ini metode wawancara dilakukan secara ofline dan online sesuai dengan prosedur kesehatan tanpa mengurangi efektifitas wawancara itu sendiri. Documentation dilakukan dengan pemeriksaan dokumen-dokumen, foto dan media lainnya yang dimiliki oleh Unit Usaha Syariah BPD Jambi. (Arikunto, 2011)

Data yang berhasil dikumpulkan kemudian diuji validitasnya dengan penelitian mendalam oleh peneliti dan triangulasi. Triangulasi adalah metode yang digunakan dalam pemeriksaaan keabhsahan suatu data dengan mengecek dan membandingkan data dan hal lain atas data yang telah dikumpulkan dilapangan. Kegiatan ini berguna utuk melihat sejauh mana keabsahan dan tingkat kepercayaan data sehingga dihasilkan data yang benarbenar terpercaya dan menghilangkan keragu-raguan.(Moleong, 2018) Triangulasi yang digunakan adalah triangulasi anatar sumber dan triangulasi antar metode.

Setelah dilakukan uji validitas pada data-data yang telah dikumpulkan sebelumnya maka dilanjutkan dengan analsisis data. Kegiatan analisis data adalah kegiatan yang sangat penting dan tak bisa ditinggalkan dalam proses penelitian karena analisis data adalah kunci utama dalam memecahkan masalah, menjawab hipotesis serta mencapai tujuan penelitian. Sugiyono mengatakan "analisis data merupakan suatu proses pencarian dan penyusunan yang sistematis atas data yang telah didapatkan dilapangan dengan berbagai metode sehingga bisa dengan mudah dipahami dan hasilnya menjadi informasi penting bagi orang lain.(Sugiyono, 2011).

Analisis data pada penelitian ini terdiri dari tiga tahapan. Tahapan pertama yaitu reduksi data. Reduksi berarti melakukan pemilahan dan perangkuman atas data-data yang dianggap penting dan berkaitan dengan fokus penelitian yang kemudian dicari pola hubungannya. Data yang didapatkan pada penelitian awal tentunya akan banyak sekali dan bisa membuat bias penelitian maka dari itu dengan adanya reduksi data akan terjadi pemilahan data, pemusatan perhatian dan penyempurnaan data sehingga peneliti akan bisa berfokus pada apa yang mejadi tujuan dalam penelitian yang dilakukannya (Sugiyono, 2011). Pada reduksi ini, peneliti menyusun data-data yang berkaitan dengan manajemen risiko pembiayan murabahah modal kerja Unit Usaha Syariah BPD Jambi dan menjauh- 
kan data diluar tema tersebut agar terbentuk data yang saling berhubungan untuk kemudian dilakukan display data.

Display data adalah tahapan kedua dalam analisis data pada penelitian ini. Display dilakukan dengan membuat uraian singkat bagian-bagian dan hubungan antar kategori flowchart dan lainnya. Dalam display, data yang telah terkumpul akan terorganisir dan tersusun membentuk pola yang saling berhubungan dan membuatnya mudah untuk dipahami (Miles, 1992). Display data yang digunakan adalah naratif deskriptif dengan membentuk pola hubungan antar data yang dideskriptifkan dalam sebuah narasi hingga membentuk infromasi utuh dan tersusun dengan baik terkait implementasi manajemen risiko pembiayaan murabahah modal kerja yang dilakukan oleh Unit Usaha Syariah BPD Jambi. Setelah display data selesai maka dilanjutkan pada tahap ketiga yaitu verification.

Verification adalah pemeriksaan yang diakhiri dengan pengambilan kesimpulan dimana kesimpulan yang diambil dapat menjawab atas masalah dan fenomena yang menjadi fokus penelitian. Kesimpulan bisa saja bersifat final maupun sementara. Jika kesimpulan awal telah disertai data-data pendukung yang valid dan konsisten ketika dilakukan penelitian ulang maka kesimpulan yang disampaikan bersifat kredibel dan final namun jika ditemukan data-data lain yang menentangya maka kesimpulan itu akan dianggap bias dan bersifat sementara serta harus dilakukan penelitian ulang yang lebih mendalam. Kesimpulan yang dikemukakan dapat berupa hubungan_klausal atau interaktif, hipotesa atau theori yang merupakan temuan baru atas suatu masalah atau fenomena yang sebelumnya dirasa masih belum jelas.(Arikunto, 2011)

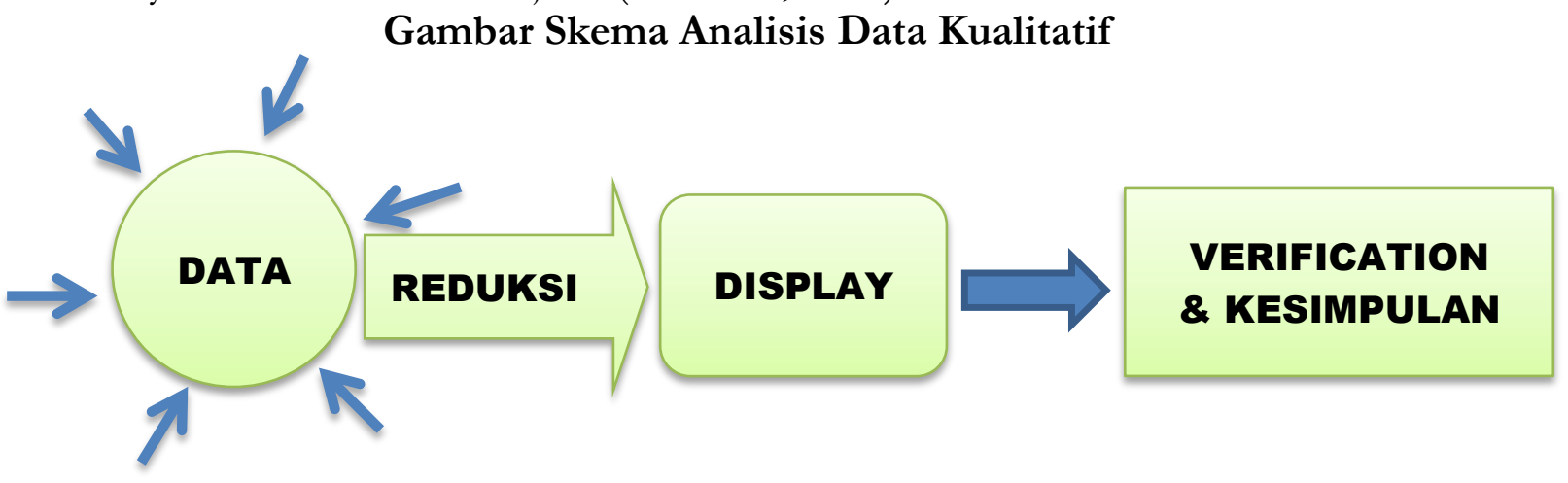

\section{Hasil dan Pembahasan}

Hasil dan pembahasan akan membahas terkait manajemen risiko, identifikasi dan pengukuran risiko, pengelolaan dan pengendalian risiko, dan efektivitas manajemen risiko.

\subsection{Manajemen Risiko}

Risiko dalam perbankan syariah cukup banyak jika dibandingkan dengan risiko perbankan konvensional. Mengacu pada Peraturan Otoritas Jasa Keuangan (POJK) No. 65.03/2016 tentang Penerapan Manajemen Risiko Bagi Bank Umum Syariah dan Unit Usaha dalam pasal satu bahwasanya ada 10 bentuk risiko yang harus dihadapi dan dikelola oleh pengelola perbankan syariah yaitu risiko pembiayaan, risiko likuiditas, risiko pasar, risiko operasional, risiko hukum, risiko strategik, risiko imbal hasil, risiko investasi, risiko reputasi dan risiko kepatuhan.(POJK.65.03/2016)

a. Risiko pembiayaan adalah risiko kerugian sehubungan dengan nasabah yang tidak mampu dan/atau tidak mau memenuhi kewajibannya dalam membayar pinjamannya 
sesuai perjanjian yang telah disepakati.(Purnamasari \& Musdholifah, 2018).

b. Risiko likuditas adalah risiko gagal bayar sehubungan dengan ketidakmampuan bank dalam memenuhi kewajibannya.(Ramadanti \& Meiranto, 2015).

c. Risiko pasar adalah risiko yang terjadi dikarenakan perubahan kondisi dan situasi pasar yang tidak sesuai dengan portofolio bank seperti perubahan nilai tukar, suku bunga dan lainnya.

d. Risiko operasional yaitu risiko yang bisa terjadi dikarenakan tidak optimalnya fungsi sistem informasi dan pengawasan internal pada bank.

e. Risiko hukum adalah risiko yang mungkin terjadi dikarenakan lemahnya aturan dan pedoman hukum yang dimiliki.

f. Risiko strategik adalah risiko yang muncul disebabkan buruknya strategi yang digunakan dalam memilih dan menetapkan bisnis yang akan dijalankan.

g. Risiko imbal hasil adalah risiko yang mungkin terjadi dikarenakan perubahan tingkat keuntungan yang diberikan perbankan.

h. Risiko investasi adalah risiko yang terjadi disebabkan bank harus ikut menanggung kerugian dalam pembiayaan bagi hasil yang diberikan kepada nasabah.

i. Risiko reputasi yaitu risiko yang bisa terjadi dikarenakan perspektif negatif masyarakat terhadap bank syariah atau citra bank buruk dimata masyarakat.

j. Risiko kepatuhan yaitu risiko yang berkemungkinan terjadi disebabkan ketidaksesuaian penyelenggaraan operasional perbankan terhadap aturan hukum dan undang-undang yang berlaku (Yusmad, 2018).

Banyaknya risiko yang harus dihadapi oleh bank syariah menuntut bank syariah harus memiliki manajemen risiko yang benar-benar efektif serta benar-benar mampu mengatasi berbagai macam kondisi yang dialami oleh bank. Bank syariah memiliki Komisaris, Direksi dan Dewan Pengawas Syariah (DPS) dalam pembagian wewewnang dan tanggung jawab terhadap manajemen risiko sebagaimana pada tabel berikut:

Tabel 2. Wewenang dan Tanggung Jawab Komisaris, Direksi dan DPS dalam Manajemen Risiko Bank Syariah (PBI13/23/2011.)

\begin{tabular}{|c|c|c|c|c|}
\hline No & Wewenang / Tanggung Jawab & Komisaris & Direksi & DPS \\
\hline 1 & $\begin{array}{l}\text { Memberikan persetujuan dan memonitoring } \\
\text { kebijakan manajemen risiko }\end{array}$ & $\sqrt{ }$ & & \\
\hline 2 & $\begin{array}{l}\text { Mengevaluasi pertanggungjawaban direksi terkait } \\
\text { kebijakan manajemen risiko }\end{array}$ & $\sqrt{ }$ & & \\
\hline 3 & $\begin{array}{l}\text { Membuat kebijakan dan strategi manajemen } \\
\text { risiko tertulis }\end{array}$ & & $\sqrt{ }$ & \\
\hline 4 & $\begin{array}{l}\text { Membuat pertanggungjawaban terhadap } \\
\text { pelaksanaan kebijakan manajemen risiko }\end{array}$ & & $\sqrt{ }$ & \\
\hline 5 & $\begin{array}{l}\text { Melakukan evaluasi dan putusan atas transaksi } \\
\text { yang membutuhkan persetujuan direksi }\end{array}$ & & $\sqrt{ }$ & \\
\hline 6 & $\begin{array}{l}\text { Mengembangkan budaya manajemen risiko pada } \\
\text { setiap tingkatan organisasi }\end{array}$ & & $\sqrt{ }$ & \\
\hline 7 & $\begin{array}{l}\text { Memastikan adanya peningkatan SDM } \\
\text { manajemen risiko }\end{array}$ & & $\sqrt{ }$ & \\
\hline 8 & $\begin{array}{l}\text { Memastikan terlaksananya fungsi manajemen } \\
\text { risiko }\end{array}$ & & $\sqrt{ }$ & \\
\hline
\end{tabular}




\begin{tabular}{|c|l|c|c|c|}
\hline 9 & $\begin{array}{l}\text { Mereview metodologi dan implmentasi } \\
\text { manajemen risiko }\end{array}$ & $\sqrt{ }$ & $\sqrt{ }$ \\
\hline 10 & $\begin{array}{l}\text { Mereview kebijakan manajemen risiko yang } \\
\text { berkaitan dengan pemenuhan prinsip syariah }\end{array}$ & $\begin{array}{l}\text { Melakukan terhadap } \\
\text { pertanggungjawaban kebijakan manajemen risiko } \\
\text { direksi yang berkaitan dengan pemenuhan prinsip } \\
\text { syariah }\end{array}$ & $\sqrt{ }$ \\
\hline
\end{tabular}

Berdasarkan Peraturan Bank Indonesia nomo 13/23 PBI/2011 tersebut dapat dilihat bahwa pertanggungjawaban terbesar dalam penerapan manajemen risiko pada bank syariah terletak pada anggota dewan direksi mulai dari merencanakan dan menetapkan strategi manajemen risiko, pelakasanaan hingga pada mereview penerapannya. Adapun dewan komisaris hanya bertanggungjawab dalam hal pesetujuan manajemen risiko yang akan diterapkan dan mengevaluasi pertanggungjawaban anggota dewan direksi. Sedangkan Dewan Pengawas Syariah bertanggungjawab dalam hal pemenuhan prinsip syariah pada manajemen risiko.

Manajemen risiko pada bank disusun dengan tujuan untuk memilah, mengidentifikasi, mengukur, mengontrol dan mengendalikan jalannya kegiatan bisnis bank agar didapatkan tingkat bahaya yang wajar serta terkoordinir. Secara lebih dalam, tujuan manajemen risiko adalah memberikan data atas berbagai bahaya yang dihadapi, memprediksi bahaya, membatasi bahaya, membatasi kemalangan atas bahaya yang terjadi, menjauhkan bank dari bahaya kemalangan yang lebih besar, dan memberikan data bahaya sebagai landasan untuk menetapkan strategi dan solusi .(Arifudin dkk., 2020)

\subsection{Identifikasi dan Pengukuran Risiko}

Unit Usaha Syariah Bank Pembangunan Daerah (BPD) Jambi menyediakan tiga jenis pembiayaan yaitu Pembiayaan Konsumtif, Pembiyaan Modal Kerja dan Pembiayaan Investasi. Diantara tiga jenis pembiayaan itu didapatilah bahwa Pembiayaan Modal Kerja menghadapi risiko yang lebih besar dibandingkan dengan jenis pembiayaan lainya. Pembiayaan Murabahah Modal Kerja yang diberikan oleh Unit Usaha Syariah Bank Pembangunan Daerah (BPD) Jambi menghadapi risiko gagal bayar yang cukup besar dimana pada periode April 2021 dari total 39 nasabah yang mendapatkan pembiayaan teradapt 28 diantaranya atau sebesar $71 \%$ masuk dalam kategori nasabah pembiayaan bermasalah. Risiko dalam pembiaayaan adalah variasi dalam hal-hal yang mempunyai kemungkinan bisa terjadi secara alami atau kemungkinan terjadinya hal-hal yang tidak diharapkan serta menjadi ancaman terhadap pembiayaan dan keuntungan financial akibat dari kejadian tersebut.(Labombang, 2011)

Secara teoritis munculnya pembiayaan bermasalah disebabkan oleh dua faktor yaitu internal dan eksternal. Faktor internal adalah faktor yang datang dari bank itu sendiri seperti kekeliruan analis dalam menganalisis pembiayaan nasabah (buman error)dan costumer relationship yang buruk. Human error biasaya terjadi pada pembiayaan dimana calon nasabah merupakan keluarga dekat maupun teman bagi analis pembiayaan sehingga penilaian lebih bersifat subjektif yang mengakibatkan fakta dan kebenaran informasi dilapangan menjadi bias. Adapun faktor eksternal adalah faktor yang datang dari nasabah seperti kegagalan bisnis dan moral hazard nasabah.(Wandayanik, 2015). Diluar itu perlu juga diwaspadai 
kegagalan bayar nasabah yang disebabkan suatu keadaan yang tidak terduga dan memaksa yang berdampak pada kondisi financial nasabah seperti bencana alam, kebakaran dan pandemi covid-19 (force majeur).

Berdasarkan hasil triangulasi sumber wawancara peneliti kepada Bapak Firsan Sadli yang menjabat sebagai pimpinan cabang, Bapak Wijaya sebagai Kepala Operasional Pembiayaan dan Ibu Muthia sebagai Ketua Satuan Kerja Audit Internal, Unit Usaha Syariah BPD Jambi telah mengidintifikasi berbagai macam risiko, sebagai berikut :

Tabel 2. Macam-macam risiko yang dihadapi Unit Usaha Syariah BPD Jambi

\begin{tabular}{|c|l|}
\hline No. & \multicolumn{1}{|c|}{ Risiko } \\
\hline 1 & Risiko akibat kesalahan dan kelalaian teller dan customer service \\
\hline 2 & Adanya pegawai bank yang melakukan fraud \\
\hline 3 & Terjadinya kesalahan dalam analisa dari Analis Pembiayaan \\
\hline 4 & Kendala teknis yang terjadi pada jaringan PLN, Telkom, dan WiFi \\
\hline 5 & Adanya nasabah yang tidak menepati janji dalam pembayaran \\
\hline 6 & Pengetahuan nasabah yang masih kurang terhadap akad pembiayaan \\
\hline 7 & Ketidaksesuaian perhitungan dengan prinsisp syariah \\
\hline 8 & Beredarnya uang palsu dimasyarakat \\
\hline 9 & Agunan yang dijaminkan bermasalah \\
\hline 10 & $\begin{array}{l}\text { Ketidaksesuaian tujuan pembiayaan yang diajukan nasabah setelah diberikan } \\
\text { pembiayaan }\end{array}$ \\
\hline 11 & Bisnis nasabah mengalami kebangkrutan ataupun masalah lain \\
\hline 12 & $\begin{array}{l}\text { Pihak penagih mendapat ancaman dan kecaman dari nasabah yang belum bisa } \\
\text { membayar hutangnya }\end{array}$ \\
\hline
\end{tabular}

Sumber : Triangulasi sumber wawancara

Adanya risiko-risiko yang telah diidentifikasi oleh BPD Jambu Unit Usaha Syariah membuat bank lebih berhati-hati dalam menjalankan bisnisnya terutama bisnis yang berhubungan langsung dengan pembiayaan yang dalam penelitian ini adalah pembiayaan murabahah modal kerja dikarekana pembiayaan murabahah modal kerja ini mendapatkan tantangan risiko yang sangat besar. Dalam penerapan manajemen risikonya, Unit Usaha Syariah BPD Jambi tidak sembarangan dalam memberikan pembiayaan modal murabahah kerja kepada nasabah. Ada aturan, SOP dan kriteria yang mesti dipenuhi oleh calon nasabah.

Identifikasi dan pengukuran risiko diterapkan oleh Unit Usaha Syariah BPD Jambi mulai dari penetapan calon nasabah dan pengajuan pembiayaan, yaitu sebagai berikut : (Hasil wawancara, observasi dan dokumentasi).

a. Persyaratan Data Diri

Calon nasabah yang mengajukan pembiayaan murabahah modal kerja harus melengkapi persayaratan formal terkait data diri calon nasabah seperti KTP, KK, Bukui Nikah, Surat Izin Usaha Perdagangan, Bukti Jaminan, data keuangan 2 tahun terakhir dan syarat lainya yang telah ditentukan oleh BDP Jambi Unit Usaha Syariah. Data diri calon nasabah tersebut menjadi data dasar utama bagi bank untuk mengindentifikasi dan mengukur risiko serta dapat dijadikan acuan bagi bank dalam memberikan pembiayaan terutama data usaha dan keuangan calon nasabah.

b. BI Checking

Selain menetapkan persyaratan data diri yang lengkap, bank selalu melakukan pemeriksaan dan pengecekan track record calon nasabah dalam pembiayaan murabahah 
perbankan melalui BI checking pada Sistem Informasi Debitur (SID). Sistem tersebut memberikan data dan informasi berkaitan dengan segala bentuk pembiayaan yang pernah dilakukan calon nasabah hingga akan dapat dijadikan pertimbangan bagi bank apakah akan memberikan pembiayaan atau tidak. Ketika pengajuan pembiayaan calon nasabah disetujui, maka pihak bank akan membuat laporan kepada Bank Indonesia (BI) untuk kemudian di input kedalam Sistem Informasi Debitur. Diterima atau tidaknya pengajuan pembiayaan calon nasabah tergantung dari skor pembiayaan dari catatan kolektibilitas. Adapun skor pembiayaan pada sistem ini adalah 1 sampai 5. Jika skor yang muncul dalam sistem adalah angka rentang 3 - 5 maka pengajuan pembiayaan calon nasabah akan ditolak dan jika skor yang muncul adalah angke rentang 1 - 2 maka pengajuan pembiayaan calon nasabah dapat diterima.

c. Survei

Nasabah yang telah melengkapi dan memenuhi persyaratan data diri serta lolos dari BI checking belum sepenuhnya menjamin akan mendapatkan pembiayaan dari BPD Jambi Unit Usaha Syariah karena masih ada tahapan penilaian berikutnya yaitu tahapan survei. Tahapan survei adalah tahapan akhir yang menjadi penentu apakah diterima atau tidaknya pengajuan pembiayaan calon nasabah.

Survei dilakukan oleh bagian analis pembiyaan dengan mendatangi tempat tinggal, tempat bisnis maupun tempat kerja calon nasabah. Survei dilakukan dengan tujuan untuk mendapatkan informasi tambahan dan data pendukung serta sebagai sarana verifikasi atas kebenaran data diri calon nasabah.

d. Analisis Pembiayaan

Analisis pembiayaan merupakan suatu kegiatan yang kompleks yang sudah dimulai dari saat nasabah melengkapi data diri, pemeriksaan BI checking dan survei. Analsisis pembiayaan adalah kegiatan analisa secara menyeluruh oleh bagian analis yang bertujuan untuk menilai segala aspek calon nasabah dalam hal pengajuan pembiayaan.

Dalam melakukan penilaian calon nasabah, analis pembiayaan murabahah modal kerja Unit Usaha Syariah BPD Jambi melakukan penilaian pada 5C + 1S. (Hasil wawancara, observasi dan dokumentasi).

\section{Character}

Character adalah sifat,watak dan kepribadian calon nasabah. Penilaian Character dilakukan oleh bank dengan tujuan untuk mengetahui dan mengenal lebih jauh tentang kepribadian calon nasabah. Bank ingin melihat apakah calon nasabah mempunyai sifat yang jujur dan memeliki komitmen terhadap perjanjian serta bertanggung jawab. Strategi yang digunakan analis pembiayaan untuk mendapatkan kesimpulan Character calon nasabah adalah dengan melihat langsung dengan mempelajari kehidupan calon nasabah selama komunikasi pengajuan pembiayaan dan bertanya serta konfirmasi kepada kelurga, kerabat maupun tetangga terdekat terkait kehidupan dan kepribadian calon nasabah.

\section{Capacity}

Capacity adalah kapasitas atau kemampuan calon nasabah dalam melakukan pembayaran atas pembiayaan yang didapatkan sesuai dengan angka dan jangka waktu yang telah disepakati. Dalam menganalisa capacity calon nasabah, Unit Usaha Syariah BPD Jambi mengunjungi tempat tinggal, tempat usaha maupun tempat kerja calon nasabah serta memperhatikan nilai barang yang diagunkan oleh calon nasabah.. Dari hasil survey tersebut akan dapat dilihat sebatas mana kemapun nasabah dalam menepati janjinya atas komitmen dalam pembiayaan. 


\section{Capital}

Capital atau modal bisa diartikan sebagai harta atau kekayaan yang dimiliki calon nasabah disaat mengajukan pembiayaan. Analis pembiayaan Unit Usaha Syariah BPD Jambi selalu memperhatikan laporan keungan, pendapatan dan pengeluaran kehidupan sehari-hari calon nasabah. Dari data keuangan tersebut analis pembiayaan akan dapat melihat seberapa besar modal atau harta kekayaan yang dimilki oleh calon nasabaj sehingga akan dapat diperkirakan sebesar apa pembiayaan bisa diberikan. BPD Jambi Unit Usaha Sayariah tidak akan memberikan pembiayaan yang jumlahnya jauh lebih besar dibandingkan modal atau kekayaan yang dimilki oleh calon nasabah

4. Collateral

Collateral adalah barang jaminan atau suatu barang berharga yang dijadikan sebagai penjamin pelunasan pembayarn pembiayaan jika seandainya nasabah mengalami gagal bayar. Unit Usaha Syariah BPD Jambi menetapkan diberlakukannya barang jaminan atas suatu pinjaman telah sesuai dengan fatwa DSN-MUI terkait jaminan dalam pembiayaan murabahah. Bagi bank sendiri, jaminan atau barang agunan menjadi sumber pembayaran kedua yang bisa didapatkan dari nasabah jika nantinya nasabah tidak bisa melunasi pembiayaannya. Ketika nasabah tidak bisa melaksanakan kewajibannya maka barang jaminan akan di eksekusi dengan cara lelang yang hasilnya akan digunakana untuk melunasi sisa pembiayaan yang harus dibayar oleh nasabah. Oleh karena itu analis pembiayaan BPD Jambi Unit Usaha Sayariah dalam hal penetapan barang jaminan akan sangat berhati-hati dalam memberikan harga taksiran karena nerkaitan dengan jumla pembiayaan yang akan diberikan. Dalam pelaksanaannya, Unit Usaha Syariah BPD Jambi hanya bisa memberikan pembiayaan sebesar $80 \%$ dari nilai total harga barang jaminan yang diajukan oleh calon nasabah.

\section{Condition}

Condition atau Condotion of economic merupakan situasi dimana analis melakukan analisa terhapap konsdisi ekonomi yang sedang terjadi dan akan berjalan beberapa tahun kedepan. Analis Unit Usaha Syariah BPD Jambi juga teliti dalam memperhatikan kondisi ekonomi yang sedang berkembang terutama pada saat pandemi Covid-19. Berdasarkan data yang didapatkan (Wawacara dan Dokumentasi) banyak calon nasabah yang gagal mendapatkan pembiayaan murabahah modal kerja pada masa pandemi Covid-19 dikarenakan analisa dari analis pembiayaan terhadap usaha calon nasabah dimana usaha calon nasabah sangat tertekan sekali akibat dari pandemi Covid-19.

\section{Sharia}

Sharia yang dimaksud adalah dimana pembiayaan yang akan diberikan atau usaha calon nasabah dalam pembiayaan murabah modal kerja benar-benar telah sesuai dengan prinsip syariah. Setelah calon nasabah telah berhasil melalui semua tahapan analisa dari analis pembiayaan, selanjutnya analis pembiayaan Unit Usaha Syariah BPD Jambi akan melakukan analisa apakah usaha yang akan dibiayai telah sesuai dengan prinsip-prinsip syariah atau tidak. Oleh karena itu pada tahapan ini analis pembiayaan bekerjasama dengan Dewan Pengawas Syariah dalam melakukan penilaian kesyariahan usaha calon nasabah

\subsection{Pengelolaan dan Pengendalian Risiko}

Unit Usaha Syariah Bank Pembangunan Daerah (BPD) Jambi telah menyadari bahwa risiko pada pembiayaan murabahah modal kerja cukup besar jika dibandingkan risiko pada pembiayaan lainnya sebagaimana terlihat pada data pembiayaan sebelumnya. 
Namun pihak bank memiliki manajemen risiko yang cukup baik untuk mengatasinya dmana telah dilakukannya identifikasi dan pengukuran risiko pada pembiayaan murabahah modal kerja tersebut. Selanjutnya, Unit Usaha Syariah BPD Jambi telah melakukan berbagai macam bentuk pengelolaan dan pengendalian risiko dalam pembiayaan murabah modak kerja sebagai berikut: (Hasil wawancara, observasi dan dokumentasi).

\section{a. Penagihan}

Setiap bank selalu menginginkan pembiayaan yang saling menguntungkan antara bank dan nasabah serta lancarnya kegiatan pembayaran oleh nasabah. Maka dari itulah bank telah berupaya menseleksi calon nasabah sedemikian ketat dengan berbagai analisa sbelum akhirnya ditetapkan sebagai nasabah penerima pembiayaan. Ketika nasabah gagal memenuhi kewajibannya dalam membayar ataupun terlambat sesuai jadwal yang telah disepakati, maka pihak pembiayaan Unit Usaha Syariah BPD Jambi akan melakukan penagihan kepada nasabah baik bertemu secara langsung maupun melaui media telfon, sms atau whatsaap (Sadli: Wawancara). Pada mulanya pihak bank hanya memberikan informasi kepada nasabah bahwa pembayaran telah jatuh tempo ataupun telah melewati batas tempo yang telah disepakati untuk kemudian diminta konfirmasi dari nasabah terkait pembayaran yang akan dilaksanakan.

\section{b. Surat Peringatan}

Nasabah yang gagal bayar atau terlambat dalam pembayaran akan mendapatkan informasi penagihan yang harus ditindaklanjuti oleh nasabah. Ketika nasabah tetap tidak bisa melakukan pmebayaran pada sudah mendapatkan informasi penagihan maka langkah selankutnya yang dilakukan oleh Unit Usaha Syariah BPD Jambi adalah dengan mengeluarkan surat peringatan pertama. Dalam surat peringatan pertama biasanya memuat keterangan tentang penurunan level pembiayaan nasabah yang semula dari "lancar" menjadi "kurang lancar" dan "dalam perhatian khusus". Perubahan status level pembiayaan nasabah ini akan masuk dalam kolektibilitas pembiayaan Unit Usaha Syariah BPD Jambi.

Setelah nasabah mendapatkan surat peringatan pertama namun tetap tidak bisa memenuhi kewajibannya maka pihak bank akan mebuatkan surat peringatan kedua yang berisi tentang penagihan pembayaran kepada nasabah dan pada tahap ini pihak bank akan mendatangi langsung kediaman nasabah, usahan ataupun tempat kerja nasabah. Jika nasabah tetap tidak bisa melakukan pembayaran maka bank akan memgeluarkan surat peringatan ketiga yang berisi pemanggilan kepada nasabah untuk melakukan negosiasi kontrak pembiayaan dengan bank dan mencari solusi atas permasalahan ketidaklancaran pembayaran. Jika ketidaklancaran pembayaran disebabkan suatu hal yang mendsak atau memaksa nasabah seperti adanya keprluan berobat atau mengalami musibah namun usaha nasabah memiliki prospek yang masih menjanjikan kedepannya, maka Unit Usaha Syariah BPD Jambi memberikan beberapa solusi: (BPD Jambi UUS: wawancara, dokumentasi dan obeservasi).

1) Rescheduling

Rescheduling atau penjadwalan ulang adalah proses dimana pihak bank memberikan penjadwalan kembali terhadap nasabah yang dirasa masih mampu melakukan pembayaran dengan cara menata ulang waktu jatuh tempo pembayaran angsuran. Adanya rescheduling ini diharapkan mampu menjaga hubungan baik antara bank dan nasabah. Pada pelaksanaannya, Unit Usaha Syariah BPD Jambi tidak bisa memberikan rescheduling ini 
kepada semua nasabah, rescheduling hanya bisa diberikan kepada nasabah yang benarbenar bisa memenuhi kewajibannya kembali atau dengan beberapa perjanjian tambahan

2) Reconditioning

Reconditioning atau disebut sebagai pengkondisian ulang adalah dimana bank memberikan kemudahan kepada nasabah yang kesulitan melakukan pembayaran dengan cara melakukan perubahan pada perpanjangan jangka waktu pembiayaan. Pada nasabah yang kesulitan dalam pembayaran pembiayaan, Unit Usaha Syariah BPD Jambi bisa memberikan perubahan pada pinjaman atau tenor waktu pembiayaan. Dengan adanya perubahan tersebut diharapkan bisa meringankan nsabah dalam melakukan pembayaran.

3) Restructuring

Restructuring adalah penataan ulang. Restructuring adalah dimana bank memberikan kemudahan kepada nasabah dengan cara perubahan pada dana atau fasilitas pembiayaan maupun perubahan apda akad kontrak. Sama halnya denga reconditioning, solusi restructuring diberikan Unit Usaha Syariah BPD Jambi kepada nasabah yang kesulitan dalam melakukan pembayaran dengan harapan bisa mmberikan kemudahan sesuai dengan kesanggupan keuangan nasabah.

4) Eksekusi Barang Jaminan

Eksekusi barang jaminan nasabah adalah langkah terakhir yang dilakukan oleh Unit Usaha Syariah BPD Jambi terhadap nasabah yang tidak bisa lagi melakukan pembayaran pembiayaan setelah diberikan berbagai solusi sebelumnya. Eksekusi barang jaminan biasanya adalah dengan melakukan lelang. Lelang oleh Unit Usaha Syariah BPD Jambi dilakukan terlebih dahulu pada pihak internal dan jika tidak terselesaikan maka akan dilelang ke publik melalui pengumuman ataupun pemberitahuan papan/spanduk iklan. Hasil dari lelang barang jaminan akan digunakan untuk melunasi sisa pembiayaan yang menjadi kewajiban nasabah. Dalam hal hasil lelang masih tidak bisa melunasi sisa pembiayaan nasabah maka akan dilakukan musyawarah bersama nabasah dan bisa masuk dalam persidangan. Berbeda halnya jika hasil lelang berlebih dari sisa pembiayaan yang menjadi tanggungan nasabah maka lebihan tersebut akan diberikan kepada nasabah. (Unit Usaha Syariah BPD Jambi : Wawancara, dokumentasi dan observasi).

\subsection{Efektivitas Manajemen Risiko Unit Usaha Syariah Bank Pembangunan Daerah Jambi}

Efektivitas merupakan pengukuran tingkat keberhasilan suatu program dimana dalam hal ini adalah terkait Manajemen risiko pembiayaan murabahah modal kerja pada Unit Usaha Syariah Bank Pembangunan Daerah (BPD) Jambi. Pengukuran efektivitas berarti pengukuran terhadap tingkat keberhasilan program bersamaan dengan hasil pencapaiannya. (Dewi \& Sedana, 2014) Manajemen risiko pembiayaan murabahah modal kerja yang diterapkan adalah dengan adanya proses indentifikasi, pengukuran, pengelolaan dan pengendalian risiko. Manajemen risiko pada pembiayaan ini diharapkan dapat meningkatkan pencapaian target pembiayaan serta dapat meminimalisir terjadinya kerugian. Efektifitas pembiyaan modal kerja murabahah disini diukur dengan melihat antara target pembiayaan dengan realisasi pencapaian.

Adapun tingkat keberhasilan manajemen risiko pembiayaan murabahah modal kerja pada Unit Usaha Sayriah BPD Jambi dapat dilihat pada perkembangan pencapaian pembiayaan sebagaimana tabel berikut: 
Tabel 3. Perkembangan Pencapaian Pembiayaan Murabahah Modal Kerja Tahun Januari 2.237 .000 .000 $\frac{2.237 .000 .000}{2.559 .380 .791}$ $x 100 \%$

87,40

\begin{tabular}{clc}
\hline Februari & $\frac{3.792 .000 .000}{1.939 .325 .100} \times 100 \%$ & 195,53 \\
\hline Maret & $\frac{4.030 .000 .000}{1.319 .269 .409} \times 100 \%$ & 305,47 \\
\hline April & $\frac{3.784 .000 .000}{1.172 .683 .920} \times 100 \%$ & 322,67 \\
\hline Mei & $\frac{3.852 .000 .000}{1.026 .098 .431} \times 100 \%$ & 375,40 \\
\hline Juni & $\frac{3.894 .000 .000}{879.512 .941} \times 100 \%$ & 442,74 \\
\hline Juli & $\frac{2.422 .000 .000}{732.927 .452} \times 100 \%$ & 330,45 \\
\hline Agustus & $\frac{2.559 .000 .000}{586.341 .962} \times 100 \%$ & 436,43 \\
\hline September & $\frac{1.783 .000 .000}{439.756 .472} \times 100 \%$ & 405,45 \\
\hline Oktober & $\frac{2.361 .000 .000}{293.170 .982} \times 100 \%$ & 805,33 \\
\hline November & $\frac{2.495 .000 .000}{146.585 .491} \times 100 \%$ & 1702,07 \\
\hline
\end{tabular}

Sumber data diolah 2021

Berdasarkan data tersebut dapat dilihat bahwa perkembangan pencapaian pembiayaan pada murabahah modal kerja cukup baik dengan adanya peningkatan pencapaian antara target dan realisasinya. Dengan demikian dapat diambil kesimpulan bahwa manajemen risiko pada pembiayaan murbahah modal kerja pada Unit Usaha Syariah BPD Jambi cukup efektif.

\section{Kesimpulan}

Pembiayaan murabahah modal kerja pada Unit Usaha Syariah Bank Pembangunan Daerah (BPD) Jambi termasuk pembiayaan dengan risiko yang cukup besar sehingga menuntut bank untuk memiliki manajemen risiko yang baik. Implementasi manajemen risiko pada pembiayaan murabahah modal oleh Unit Usaha Syariah BPD Jambi sudah cukup baik dimana telah dilakukan berbagai upaya dalam pengidentifikasian, pengukuran, pengelolaan dan pengendalian risikonya. Manajemen risiko yang telah disusun oleh Unit Usaha Syariah BPD Jambi tergolong efektif dengan adanya peningkatan antara capaian dan realisasi pencapaiannya.

\section{REFERENSI}

Arifudin, O., Wahrudin, U., \& Rusmana, F. D. (2020). Manajemen Risiko. Penerbit Widina. Arikunto, S. (2011). Prosedur Penelitian: Suatu Pendekatan Praktik (VI, Vol. 14). Rineka Cipta. 
Manajemen Risiko Unit Usaha Syariah Bank Pembangunan Daerah Jambi...

Bambang Rianto Rustam. (2013). Manajemen Risiko Perbankan Syariah di Indonesia. Salemba Empat.

Bank Jambi. (t.t.). Diambil 19 Agustus 2021, dari http://bankjambi.co.id/?v=pr\&id=103

Dewi, N. M. I. P., \& Sedana, I. B. P. (2014). Efektivitas Manajemen Risiko Dalam Mengendalikan Risiko Kredit Di PT Bank Rakyat Indonesia. dalam E-Jurnal Manajemen Unud, 6(8).

Eka Yudiana, F. (2014). Manajemen Pembiayaan Bank Syariab (Vol. 1). STAIN Salatiga Press.

Fatwa DSN No. 111 Tahun 2017. (t.t.). Google Docs. Diambil 19 Agustus 2021, dari https://drive.google.com/file/d/1PJqKTaew1MoSsxlJpXnblz5x2DKhSlfq/view?u $\mathrm{sp}=$ sharing\&usp $=$ embed_facebook

Idroes, F. N. (2008). Manajemen Risiko Perbankan. Rajawali Pers.

Karim, A. A. (2007). Bank Islam: Analisis Fiqih dan Kenangan (ke 3, Vol. 3). Pt. Raja Grafindo Persada2.

Labombang, M. (2011). Manajemen risiko dalam proyek konstruksi. SMARTek, 9(1).

Miles, M. B. (1992). Analisis data kualitatif: Buku sumber tentang metode-metode baru. Universitas Indonesia Library; UI-Press. http://lib.ui.ac.id

Moleong, L. J. (2018). Metodologi Penelitian Kualitatif (38 ed.). Bandung: PT Remaja Rosdakarya.

PBI13/23/2011. (t.t.). Diambil 28 Agustus 2021, dari https://www.ojk.go.id/Files/201403/pbi_132311_1394525595.pdf

Prasastinah Usanti, T. (2019). Pengelolaan Risiko Pembiayaan Di Bank Syariah. Adil: Jurnal Hukum, 3(2), 408. https://doi.org/10.33476/ajl.v3i2.817

Purnamasari, A. E., \& Musdholifah, M. (2018). Analisis Faktor Eksternal dan Internal Bank terhadap Risiko Pembiayaan Bank Umum Syariah di Indonesia Periode 20122015. BISMA (Bisnis dan Manajemen), 9(1), 13-25.

Ramadanti, F., \& Meiranto, W. (2015). Analisis Pengaruh Risiko Likuiditas Terhadap Profitabilitas Perusahaan Perbankan di Indonesia. Diponegoro Journal of Accounting, $4(2), 447-456$.

SALINAN-POJK.6 BUKU.pdf. $\quad$ (t.t.). Diambil 19 Agustus 2021, dari https://www.ojk.go.id/id/kanal/perbankan/regulasi/peraturan-

ojk/Documents/Pages/pojk-kegiatan-usaha-dan-jaringan-kantor-berdasarkanmodal-inti-bank/SALINAN-POJK.6\%20BUKU.pdf

Snapshot Perbankan Syariah Juni 2020.pdf. (t.t.). Diambil 19 Agustus 2021, dari https://www.ojk.go.id/id/kanal/syariah/berita-dan-

kegiatan/publikasi/Documents/Pages/Snapshot-Perbankan-Syariah-Juni-

2020/Snapshot\%20Perbankan\%20Syariah\%20Juni\%202020.pdf

Sofyan, S. (2017). Analisis Penerapan Manajemen Risiko Pembiayaan Pada Lembaga Pembiayaan Syariah. Bilancia: Jurnal Studi Imu Syariah dan Hukum, 11(2), 359-390.

Sugiyono. (2011). Metode Penelitian Kombinasi (Mixed Methods). Alfabeta.

Syahrizal, A., \& Anita, E. (2021). Analisis Manajemen Keuangan Pondok Pesantren (Studi Pada Pondok Pesantren Isti'dadul Mu'allimien Jambi). Finansha-Journal Of Sharia Financial Management, 2(1), 26-37.

Ulfa, N. (2019). Pelaksanaan Perjanjian Pembiayaan Murabahah Investasi Usaha Kecil, Mikro, Menengah Di Kantor Pusat Operasional Pt. Bank Aceh Syariah. ETD 
Unsyiah, 1(1),

Article

1.

http://etd.unsyiah.ac.id/index.php?p=show_detail\&id=58288

Wandayanik, R. (2015). Implementasi Manajemen Risiko Pembiayaan Murabahah di Bank BNI Syariah Kantor Cabang Pembantu Mojokerto. el-Qist: Journal of Islamic Economics and Business (JIEB), 5(1), 963-979.

Yusmad, M. A. (2018). Aspek Hukum Perbankan Sayriah dari Teori ke Praktik (1 ed.). CV. Budi Utama.

Yusuf, M. (2014). Metode Penelitian: Kuantitatif, Kualitatif dan Penelitian Gabungan (1 ed.). Kencana. 